\title{
Determination of Physicochemical Parameters of Effluents at Discharge Points into the New Calabar River along Rumuolumeni Axis, Port Harcourt, Rivers State, Niger Delta, Nigeria
}

\section{Edori OS $^{*}$ and Nna PJ}

Department of Chemistry, Faculty of Natural and Applied Science, Ignatius Ajuru University of Education, Rumuolumeni, PMB 5047, Port Harcourt, Rivers State, Nigeria "Corresponding author: Edori OS, Department of Chemistry, Faculty of Natural and Applied Science, Ignatius Ajuru University of Education, Rumuolumeni, PMB 5047, Port Harcourt, Rivers State, Nigeria, Tel: 08038984391; E-mail: onisogen.edori@yahoo.com

Received: August 10, 2018; Accepted: August 17, 2018; Published: August 24, 2018

Copyright: (C) 2018 Edori OS, et al. This is an open-access article distributed under the terms of the Creative Commons Attribution License, which permits unrestricted use, distribution, and reproduction in any medium, provided the original author and source are credited.

\begin{abstract}
Water samples collected from three effluents discharge points into the New Calabar River were analyzed for physicochemical parameters using standard methods. The physicochemical parameters analyzed were colour, odor, temperature, $\mathrm{pH}$, conductivity, total dissolved solids (TDS), turbidity, total suspended solids (TSS), dissolved oxygen (DO), biochemical oxygen demand (BOD), chemical oxygen demand (COD), sulphate $\left(\mathrm{SO}_{4}{ }^{2-}\right)$, nitrate $\left(\mathrm{NO}_{3}{ }^{-}\right)$, phosphate $\left(\mathrm{PO}_{4}{ }^{3-}\right)$ and chloride $\left(\mathrm{Cl}^{-}\right)$. The result obtained showed that at lwofe Jetty the water was colourless and odorless but had slight colour and odor at the police post station and Minipiti station. The range for the parameters obtained in the seasons were: temperature $\left(26.4 \pm 1.10-29.0 \pm 2.38^{\circ} \mathrm{C}\right), \mathrm{pH}(3.43 \pm 0.24-5.06 \pm 1.42)$, conductivity $(11.60 \pm 2.68-15.61 \pm 3.01 \mu \mathrm{S} / \mathrm{cm})$, TDS $(6.53 \pm 0.56-8.89 \pm 0.98 \mathrm{mg} / \mathrm{L})$, turbidity $(9.42 \pm 2.68-17.90 \pm 3.09 \mathrm{mg} / \mathrm{L})$, TSS $(20.53 \pm 3.27-33.51 \pm 6.25 \mathrm{mg} / \mathrm{L})$, DO $(2.62 \pm 0.02-5.02 \pm 0.31 \mathrm{mg} / \mathrm{L}), \mathrm{BOD}(4.28 \pm 1.08-6.11 \pm 1.33 \mathrm{mg} / \mathrm{L})$, $\operatorname{COD}(13.54 \pm 3.93-19.16 \pm 2.10 \mathrm{mg} / \mathrm{L}), \mathrm{SO}_{4}{ }^{2-}(65.92 \pm 12.50-346.72 \pm 23.22 \mathrm{mg} / \mathrm{L}), \mathrm{NO}_{3}{ }^{-}(0.32 \pm 0.01-0.53 \pm 0.04$ $\mathrm{mg} / \mathrm{L}), \mathrm{PO}_{4}{ }^{3-}(0.34 \pm 0.01-0.68 \pm 0.03 \mathrm{mg} / \mathrm{L})$ and $\mathrm{Cl}^{-}(4041 \pm 80.50-9411 \pm 100.68 \mathrm{mg} / \mathrm{L})$. Generally, the result indicated that colour, odor, $\mathrm{pH}$, turbidity, $\mathrm{DO}, \mathrm{BOD}, \mathrm{COD}$, and $\mathrm{Cl}^{-}$do not meet the $\mathrm{WHO}$ standard for portable water, therefore the water is polluted. The authorities responsible for effluents discharge regulation should therefore monitor the different input sources in order to prevent further increase in pollution of the river.
\end{abstract}

Keywords: Physicochemical parameters; Pollution; Wastewater; Aquatic organisms

\section{Introduction}

It is a known fact that the process in which wastewater or effluents are released into rivers are accompanied by the presence of large quantities of chemical pollutants [1]. Most of the effluents discharged into rivers are either not treated or poorly treated. This may become deleterious to aquatic organisms and other organisms which may eventually make use of such water [2]. Due to ineffective purification systems, wastewater may become seriously dangerous leading to the accumulation of toxic products in the receiving water bodies, with potentially serious consequences on the ecosystem [3]. Furthermore, when an untreated water (whether domestic or industrial) is discharged into any aquatic environment, there is the probability of alteration of the general water chemistry of that water, thus implying that the water has been polluted $[4,5]$. This is because effluents discharge is usually accompanied with different chemical components. Urban settlements and its associated industrial growth increases human activities within an environment. Sudden rise in human and industrial activities culminates in the production of more waste, which in most cases are discharged into aquatic environments. These chemical laden wastes are harmful to the environment and as such cause serious damage to both plants and animals [6]. Rivers State generally and Port Harcourt in particular, is associated with heavy rains and accompanied with gathering of large pools of water on the road. To overcome this, drainages are built and channeled to rivers. The runoffs from these drainages always transport or transfer all the contents in the drainage to the river. Wastes form homes as well as those from the industries are also carried along. This therefore, add to the general pollution burden of the aquatic environment. One of the pollutants that is commonly associated with effluents discharge is heavy metals. They are known poisons or toxicant at certain concentrations on water and food, even though some may be essential at low concentrations [7]. Heavy metals are dangerous because they tend to bioaccumulate in plant and animal tissues. Bioaccumulation results when there is an increase in the concentration of a chemical in a biological organism over time, compared to the natural concentration of chemicals in environment [8]. However, man's increased ability to utilize remarkable properties of metals has always resulted in little or significantly large quantities of these metals being discharged into the surrounding as waste and subsequently the environment. This study therefore examined the physicochemical parameters and concentrations of heavy metals at effluents discharge points into the New Calabar River along the Rumoulumeni axis of Port Harcourt, Rivers State.

\section{Materials and Methods}

\section{Study area}

The water samples were collected from three (3) different discharged points (various locations) namely, Iwofe jetty, Minikpiti and Police Post (Figure 1). The samples were all collected within the Rumuolumeni axis in Obio/Akpor Local Government Area of Rivers State, Nigeria. 
Citation: Edori OS, Nna PJ (2018) Determination of Physicochemical Parameters of Effluents at Discharge Points into the New Calabar River along Rumuolumeni Axis, Port Harcourt, Rivers State, Niger Delta, Nigeria. J Environ Anal Toxicol 8: 585. doi: $10.4172 / 2161-0525.1000585$

Page 2 of 5

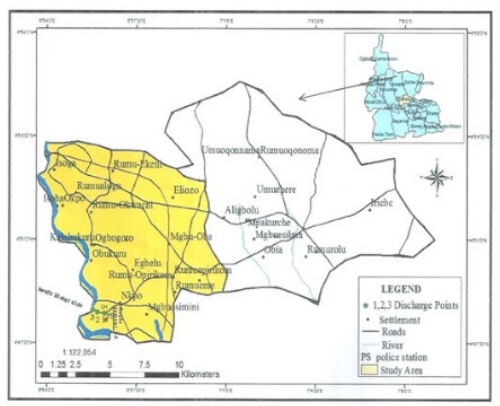

Figure 1: Rumuolumeni South west showing Drainage Discharge Points.

\section{Sample collection}

Sampling was done during the dry season and wet/ rainy season. Water samples were collected during low tide with sample collection bottle or tube at a depth of $10 \mathrm{~cm}$ below the water surface. After collection the samples were placed in ice pack containers and then transferred to the laboratory where they were stored at a $4^{\circ} \mathrm{C}$. The precleaned sample bottles were initially rinsed with the water samples before collection.

\section{Physicochemical parameters analysis}

Colour and odour of the samples were determined by visual and physiological (subjective) examination. $\mathrm{pH}$, conductivity, $\mathrm{DO}$, turbidity and TDS were examined on the spot (in situ) with a hand-held meter HANNA pH meter (Model: HI 98129, Hanna Instruments, California, USA). For the $\mathrm{pH}$, the probes (electrodes) on the instrument were first placed or dipped into two different solutions of acid buffered at $\mathrm{pH}$ of 4.0 (acid $\mathrm{pH}$ ) and 9.0 (alkaline $\mathrm{pH}$ ) before placing them into the samples to take readings. After which the probes were washed or rinsed in deionized water before the other parameters were measured. Each of the parameters was examined by pressing the button which has the parameter written above it and the value recorded against that sample. Temperature was measured on site with a mercury thermometer. BOD was measured with DO instrument after keeping the sample in the dark for five days. The concentrations of the anions namely chloride, Phosphate, nitrate and sulphate and COD were determined using standard methods for analysis of water and wastewater [9] using $\mathrm{HACH}$ spectrophotometer instrument model No. 3900 DR USA.

\section{Results and Discussion}

The concentrations of the different physicochemical parameters from the different stations in the different seasons is shown on Tables $1-3$.

\section{Colour and odour}

The water samples from the Iwofe Jetty station were odourless and colourless, while those of the Minipiti and Police post stations possessed odour and colour. Colour and Odour in water do not exist on their own, but could be traceable to the presence of organic or inorganic contaminants introduced into the water [10]. Some heavy such as iron, copper, zinc etc at high concentrations introduce odour and taste to water. Odour and taste always come together. When water is odourous or has colour, that water is usually rejected by user or consumers. Furthermore, the presence of colour and odour in water is an indication of the presence of volatile organic compounds such as benzene, formaldehyde, toluene, xylene, etc. [11]. The colour and odour from the two stations may have resulted from the stagnant nature of the water which has to wait until high tide before having direct contact with the river water, when compared to that of Iwofe jetty which is discharged directly into the river, which the river current carry away immediately.

\section{Temperature}

The temperature of the water at the various station were within acceptable limits of the compared standards. The range of temperature was between $27.0 \pm 1.40-29.0 \pm 2.38^{\circ} \mathrm{C}$ in the dry season, while in the rainy season the range was $26.4 \pm 1.1-27.0 \pm 3.1^{\circ} \mathrm{C}$. Temperature is a valuable factor in ecological and physical assessment of water quality. This is because of its influence on both biological and non-biological components of the environment, thus influencing the behaviour of organisms and the proper functioning of an ecosystem [12]. The temperature of any aquatic environment has profound roles to play in reproduction, growth, feeding and immunity of all aquatic or water dwelling plants and animals. If the temperature is too high, the oxygen content of the water is reduced and the function of cells of living organisms is altered, which has direct fatal or mortal consequences on such organisms inhabiting that environment [13].

\section{$\mathrm{pH}$}

The $\mathrm{pH}$ values obtained from the different locations in both seasons fall within the range of 3.43 $\pm 0.24-5.06 \pm 1.42$. However, the $\mathrm{pH}$ values were higher in the rainy season than the dry season. The increase in the $\mathrm{pH}$ values during the rainy season may have resulted from the dilution factor due to increased water input from rain. The values obtained were lower than the recommended $\mathrm{pH}$ value for drinking or domestic purposes by the sited agencies [14]. The $\mathrm{pH}$ values obtained in the different discharge points were all acidic in nature similar to those observed in another study [15]. When water is acidic, it enhances corrosion of metal pipes, cement wall and plumping processes, but when the water is alkaline in nature, it shows that the water is disinfected and suitable for use $[10,16]$. The acidic nature of the water samples from the various sample points can be attributed to the type of effluents discharged into the river through domestic and industrial activities. When the $\mathrm{pH}$ values of any water is at the extremes, the taste and sweetness of the water is affected. The effectiveness of biochemical reactions depends on $\mathrm{pH}$. Furthermore, other important reactions and parameters in water are governed by the concentration of the hydronium ion $\left(\mathrm{H}^{+}\right)$. Such parameters include ammonia and solubility of metal ions [11].

\begin{tabular}{|l|l|l|l|}
\hline \multirow{2}{*}{ Parameter } & \multicolumn{3}{|c|}{ Location } \\
\cline { 2 - 4 } & Iwofe Jetty & Minipiti & Police Post \\
\hline Colour & Colourless & Slightly coloured & Slightly coloured \\
\hline Odor & Odorless & Foul odor & Foul odor \\
\hline Temperature (oC) & $29.0 \pm 2.38$ & $27.5 \pm 1.33$ & $27.0 \pm 1.40$ \\
\hline $\mathrm{pH}$ & $3.43 \pm 0.24$ & $4.26 \pm 0.33$ & $4.15 \pm 0.02$ \\
\hline
\end{tabular}


Citation: Edori OS, Nna PJ (2018) Determination of Physicochemical Parameters of Effluents at Discharge Points into the New Calabar River along Rumuolumeni Axis, Port Harcourt, Rivers State, Niger Delta, Nigeria. J Environ Anal Toxicol 8: 585. doi: $10.4172 / 2161-0525.1000585$

Page 3 of 5

\begin{tabular}{|l|l|l|l|}
\hline $\begin{array}{l}\text { Conductivity } \\
(\mu \mathrm{S} / \mathrm{cm})\end{array}$ & $15.61 \pm 3.01$ & $11.60 \pm 2.68$ & $13.04 \pm 3.11$ \\
\hline $\mathrm{TDS}(\mathrm{mg} / \mathrm{L})$ & $8.89 \pm 0.98$ & $6.53 \pm 0.56$ & $7.01 \pm 0.37$ \\
\hline Turbidity $(\mathrm{NTU})$ & $15.07 \pm 2.66$ & $10.84 \pm 1.04$ & $9.42 \pm 2.68$ \\
\hline $\mathrm{TSS}(\mathrm{mg} / \mathrm{L})$ & $31.31 \pm 4.91$ & $20.53 \pm 3.27$ & $24.52 \pm 4.12$ \\
\hline $\mathrm{DO}(\mathrm{mg} / \mathrm{L})$ & $2.62 \pm 0.02$ & $3.42 \pm 0.01$ & $3.72 \pm 0.03$ \\
\hline $\mathrm{BOD}(\mathrm{mg} / \mathrm{L})$ & $6.11 \pm 1.33$ & $4.40 \pm 0.53$ & $4.81 \pm 1.80$ \\
\hline $\mathrm{COD}(\mathrm{mg} / \mathrm{L})$ & $19.16 \pm 2.10$ & $16.59 \pm 3.62$ & $17.17 \pm 2.54$ \\
\hline $\mathrm{SO}_{4}{ }^{2-}(\mathrm{mg} / \mathrm{L})$ & $74.16 \pm 8.35$ & $290.82 \pm 10.23$ & $346.72 \pm 23.22$ \\
\hline $\mathrm{NO}_{3}{ }^{-}(\mathrm{mg} / \mathrm{L})$ & $0.53 \pm 0.04$ & $0.39 \pm 0.12$ & $0.34 \pm 0.00$ \\
\hline $\mathrm{PO}_{4}{ }^{3-}(\mathrm{mg} / \mathrm{L})$ & $0.68 \pm 0.03$ & $0.46 \pm 0.01$ & $0.34 \pm 0.01$ \\
\hline $\mathrm{Cl}^{-}(\mathrm{mg} / \mathrm{L})$ & $9.411 \pm 100.68$ & $7.979 \pm 80.71$ & $6.067 \pm 98.94$ \\
\hline
\end{tabular}

Table 1: Physicochemical parameters of water samples from the discharge points into the New Calabar River in the dry season.

\section{Conductivity}

The values observed for conductivity in this work were lower than the desired or recommended value by WHO. There was no difference in the values obtained in the various stations within the seasons. The expression of the ability of water to conduct electricity is known as conductivity. The conductivity of any water or aquatic body is dependent on concentration of ions or current carrying species present in the water [17]. Since conductivity is a function of the ionic content of the sample, which gives an idea of the amount of dissolved ions or electrolytes present in the sample, it becomes a very important parameter or tool to indicate or examine the hardness and alkalinity of water [18]. The values obtained for conductivity in this work were quite low when compared with those of Abdar et al. [18] in Morna Lake, Shirala, India and those observed by Sharma et al. [17] in Satluj River, Himachal Pradesh, India.

\section{Total Dissolved Solids (TDS)}

The mean value of TDS observed in this work was $7.31 \mathrm{mg} / \mathrm{L}$, a value which was far below the WHO standard of 250-500 mg/L. TDS is a measure of both inorganic an organic matter that are dissolved or are found in solution in water [16]. The extent of pollution of any water or aquatic environment can be expressed in terms of the amount, value or quantity of TDS present. The degree of contamination or pollution of water has direct proportionality to the concentration of TDS. It is expected that the TDS value in the rainy season should be higher than those of the dry season due to water runoffs as was observed in another study $[19,20]$, but this was not so. This situation may have arisen as a result of the time and nature of sampling or from the built of the drainage from which the effluent and rain water are being discharged. To properly manage any treatment system, the analysis of TDS should be properly done since it is a very important parameter which controls both physical and biological wastewater treatment or purification processes [21].

\section{Turbidity}

Turbidity is a measure of the transparency or opacity of water. Any water which contains high level of suspended and dissolved particles have the tendency to possess very high values of turbidity. The observed turbidity values were slightly higher in the rainy season when compared to those of the rainy seasons. The average values obtained was $12.48 \mathrm{NTU}$ which was 2.5 times the WHO value of $5 \mathrm{NTU}$. When there is increased turbidity of waterbody, it interferes with the penetration of light through water. This will impairment or destroy the nature of aquatic life exhibited by biotic organisms and also depreciate the value of surface water [22]. During the wet or rainy season, runoffs usually wash off surface soil into water bodies thus increasing the concentration of suspended solids which subsequently increase the turbidity [23].

\section{Total Suspended Solids (TSS)}

The mean value of total suspended solids was $26.97 \mathrm{mg} / \mathrm{L}$. however, the values at the Iwofe Jetty in both seasons were slightly higher than the standard requirement of $30 \mathrm{mg} / \mathrm{L}$ by WHO. The values of TSS observed in this work was higher than those observed in another study [24]. When there is increased TSS, the turbidity of the water is increased. Land use system such as farming, construction, mining, etc., exposes soil surfaces to erosion and runoffs, which adds to the aquatic load of suspended particles. Suspended solids or particles in waterbody is more of a function of natural occurrence or causes rather than anthropogenic. Suspended solid particles are either organic or inorganic components such as algae, silt and sediment. Another factor that can cause increase in the amount of TSS is re-suspension of sediment resulting from seasonal water variations and flows. However, excess concentrations above the expected background value is a consequence of direct or indirect human activity.

\section{Dissolved Oxygen (DO)}

The average value of DO observed was $3.74 \mathrm{mg} / \mathrm{L}$ as against the 10 $\mathrm{mg} / \mathrm{L}$ recommended by WHO. The values were low in all the stations and seasons. DO is considered as one of the most important water quality parameters because aquatic life depends on the amount of oxygen present in the water to be utilized by aquatic biota. The concentration of Dissolved oxygen in water is very informative due to the fact that it can be used to ascertain the level of bacterial activity, photosynthesis, nutrients availability, stratification and survival of fishes [25]. Dissolved oxygen (DO) is reduced in aquatic media during dry season due to increase in temperature and enhanced microbial activity [26]. The above statement agrees with findings of this work where lower values of DO was observed in dry season than the rainy season. High temperatures reduces solubility of gases in water and also sunlight facilitates photosynthetic processes by phytoplankton, by utilizing more $\mathrm{CO}_{2}$ and giving off oxygen, Thus, accounting for the higher values of DO observed during wet or rainy season [27].

\section{Biochemical Oxygen Demand (BOD)}

The average BOD values observed in this work was $4.92 \mathrm{mg} / \mathrm{L}$, which was higher than the WHO recommended value of $4.0 \mathrm{mg} / \mathrm{L}$. The values obtained in the present work is far lower than those observed by Yapo et al. [28] from waste water in Abijan, which was $14500 \mathrm{mg} / \mathrm{L}$. BOD is used to express the level contamination of water by organic material. It is the quantity or level of oxygen dissolved in water that is needed or required for biochemical oxidation, breakdown or 
Citation: Edori OS, Nna PJ (2018) Determination of Physicochemical Parameters of Effluents at Discharge Points into the New Calabar River along Rumuolumeni Axis, Port Harcourt, Rivers State, Niger Delta, Nigeria. J Environ Anal Toxicol 8: 585. doi: $10.4172 / 2161-0525.1000585$

Page 4 of 5

disintegration of organic and some certain inorganic materials by micro-organism [29]. It is used to assess the degree of pollution of surface and ground waters where there is disposal of domestic and industrial effluents [30]. Although the WHO maximum requirement for BOD in water is $4.0 \mathrm{mg} / \mathrm{L}$, yet $1.0 \mathrm{mg} / \mathrm{L}$ is most appropriate for drinking water. Values of BOD up to $5.0 \mathrm{mg} / \mathrm{L}$ gives a serious doubt on the portability of water due to the presence of bio-organisms.

\section{Chemical Oxygen Demand (COD)}

The mean value of COD in this research was $16.41 \mathrm{mg} / \mathrm{L}$, which was higher than the WHO recommended value of $10 \mathrm{mg} / \mathrm{L}$. the highest concentration was observed at the Iwofe Jetty in the dry season, with a concentration of $19.16 \mathrm{mg} / \mathrm{L}$. COD is also a measure of the concentration of organic material pollution or pollution in water. The chemical oxidation of organic matter present requires a certain amount of dissolved oxygen that should be present. It is the quantity of dissolved oxygen that is used up to achieve this oxidation that is referred to as COD [17]. COD like BOD is an important indicator of environmental health of any surface water before supply for consumption.

\begin{tabular}{|l|l|l|l|}
\hline \multirow{2}{*}{ Parameter } & \multicolumn{3}{|c|}{ Location } \\
\cline { 2 - 4 } & Iwofe Jetty & Minipiti & Police Post \\
\hline Colour & Colourless & Slightly coloured & Slightly coloured \\
\hline Odor & Odorless & Foul odor & Foul odor \\
\hline Temperature $\left({ }^{\circ} \mathrm{C}\right)$ & $27.0 \pm 3.1$ & $26.5 \pm 2.0$ & $26.4 \pm 1.1$ \\
\hline $\mathrm{pH}$ & $4.63 \pm 0.33$ & $5.06 \pm 1.42$ & $4.89 \pm 1.01$ \\
\hline $\begin{array}{l}\text { Conductivity } \\
(\mu \mathrm{S} / \mathrm{cm})\end{array}$ & $14.52 \pm 2.98$ & $12.71 \pm 1.67$ & $12.42 \pm 2.66$ \\
\hline TDS (mg/L) & $7.69 \pm 2.11$ & $6.73 \pm 1.33$ & $7.02 \pm 1.45$ \\
\hline Turbidity (NTU) & $17.90 \pm 3.09$ & $11.72 \pm 2.63$ & $9.98 \pm 2.68$ \\
\hline TSS (mg/L) & $33.51 \pm 6.25$ & $25.28 \pm 4.96$ & $26.65 \pm 3.78$ \\
\hline $\mathrm{DO}(\mathrm{mg} / \mathrm{L})$ & $3.26 \pm 0.02$ & $4.42 \pm 0.28$ & $5.02 \pm 0.31$ \\
\hline $\mathrm{BOD}^{(\mathrm{mg} / \mathrm{L})}$ & $5.12 \pm 0.23$ & $4.28 \pm 1.05$ & $4.80 \pm 0.87$ \\
\hline $\mathrm{COD}(\mathrm{mg} / \mathrm{L})$ & $17.32 \pm 1.66$ & $13.54 \pm 3.93$ & $14.67 \pm 2.67$ \\
\hline $\mathrm{SO}_{4}{ }^{2-}(\mathrm{mg} / \mathrm{L})$ & $65.92 \pm 12.50$ & $240.83 \pm 28.19$ & $300.41 \pm 16.60$ \\
\hline $\mathrm{NO}_{3}{ }^{-}(\mathrm{mg} / \mathrm{L})$ & $0.51 \pm 0.08$ & $0.400 \pm 0.00$ & $0.32 \pm 0.01$ \\
\hline $\mathrm{PO}{ }_{4}{ }^{3-}(\mathrm{mg} / \mathrm{L})$ & $0.56 \pm 0.00$ & $0.34 \pm 0.11$ & $0.38 \pm 0.05$ \\
\hline $\mathrm{Cl}^{-}(\mathrm{mg} / \mathrm{L})$ & $6.922 \pm 87.32$ & $4,885 \pm 77.10$ & $4,041 \pm 80.50$ \\
\hline
\end{tabular}

Table 2: Physicochemical parameters of water samples from the discharge points into the New Calabar River in the Rainy season.

\section{Sulphate $\left(\mathrm{SO}_{4}{ }^{2-}\right)$}

The mean concentration of Sulphate $\left(\mathrm{SO}_{4}{ }^{2-}\right)$ in the present work was $219.81 \mathrm{mg} / \mathrm{L}$, which was lower than the WHO set limit of 250-500 $\mathrm{mg} / \mathrm{L}$. The highest value of $346.72 \pm 23.22 \mathrm{mg} / \mathrm{L}$ was observed at the Police post station, which is within the set limit for drinking water. The values obtained for sulphate were higher than those of other authors $[31,32]$ in a Nigerian and Wales rivers respectively.

\section{Nitrate $\left(\mathrm{NO}_{3}^{-}\right)$}

The mean value of nitrates in the present research work was 0.415 $\mathrm{mg} / \mathrm{L}$. The highest concentration of was observed at the Iwofe Jetty station. The observed values from the different stations were lower that the WHO limit of $50 \mathrm{mg} / \mathrm{L}$ for drinking water. The values obtained in this work though very low, yet are higher than the values obtained by Abdar et al. [18] in Morna Lake, Shirala, India, where he obtained a concentration range of $0.0157-0.032 \mathrm{mg} / \mathrm{L}$. Proteins, chlorophyll and other organic matter are the sources by which nitrates are transmitted to river.

\section{Phosphate $\left(\mathrm{PO}_{4}{ }^{3-}\right)$}

Phosphates in aquatic environment in most cases are present in the form of Orthophosphates $\left(\mathrm{PO}_{4}{ }^{3-}\right)$. In the present research the observed mean phosphate was $0.46 \mathrm{mg} / \mathrm{L}$, which was a little lower than the WHO value of $0.5 \mathrm{mg} / \mathrm{L}$. The highest concentration of phosphorus was observed in the dry season at the Iwofe Jetty station, which was $0.68 \pm$ $0.03 \mathrm{mg} / \mathrm{L}$. Sources of phosphate enrichment in any waterbody can be from runoffs, decay of organic materials, excreta from animals and effluents from industrial discharges from fertilizer companies. Phosphate explosion results in algal growth and subsequent eutrophication of lakes or stagnant pool of water [10].

\section{Chloride $\left(\mathrm{Cl}^{-}\right)$}

The mean concentration of chloride ion in the water samples in this research was $6550.83 \mathrm{mg} / \mathrm{L}$, which was higher than the $250 \mathrm{mg} / \mathrm{L}$ required by WHO. The very high level of chloride in the present work may have arisen from inflow of sea water during high tide. Sources of chloride in water arise majorly from re-suspension of chloride contaminated sediments, sewage and industrial discharges. One major effect of chloride in water is the enhancement of the electrical conductivity of water and corrosion of metals on contact with the water. Metals in the presence of chlorides reacts to give soluble salts [14], thereby increasing the concentration of metals in water. Both galvanic and pitting corrosion are enhanced by the presence of chlorides $[14,33]$.

\begin{tabular}{|l|l|l|l|}
\hline Parameters & Present Work & WHO Standard & SON Standard \\
\hline Colour & Slightly coloured & Unobjectionable & Unobjectionable \\
\hline Odour & Foul odour & Unobjectionable & Unobjectionable \\
\hline Temperature $\left({ }^{\circ} \mathrm{C}\right)$ & 27.23 & $26.5-32$ & Ambient \\
\hline pH & 4.40 & $6.5-8.5$ & $6.5-8.5$ \\
\hline Conductivity $(\mu \mathrm{S} / \mathrm{cm})$ & 13.32 & 500 & 1000 \\
\hline TDS $(\mathrm{mg} / \mathrm{L})$ & 7.31 & $250-500$ & 500 \\
\hline Turbidity $(\mathrm{NTU})$ & 12.48 & 5 & 5 \\
\hline TSS $(\mathrm{mg} / \mathrm{L})$ & 26.97 & 30 & 30 \\
\hline $\mathrm{DO}^{(\mathrm{mg} / \mathrm{L})}$ & 3.74 & $5-10$ & 10 \\
\hline $\mathrm{BOD}(\mathrm{mg} / \mathrm{L})$ & 4.92 & 4 & 500 \\
\hline $\mathrm{COD}^{(\mathrm{mg} / \mathrm{L})}$ & 16.41 & 10 & 50 \\
\hline $\mathrm{SO}_{4}{ }^{2-}(\mathrm{mg} / \mathrm{L})$ & 219.81 & $250-500$ & 500 \\
\hline $\mathrm{NO}_{3}{ }^{-}(\mathrm{mg} / \mathrm{L})$ & 0.415 & 10 & 50 \\
\hline
\end{tabular}


Citation: Edori OS, Nna PJ (2018) Determination of Physicochemical Parameters of Effluents at Discharge Points into the New Calabar River along Rumuolumeni Axis, Port Harcourt, Rivers State, Niger Delta, Nigeria. J Environ Anal Toxicol 8: 585. doi: $10.4172 / 2161-0525.1000585$

Page 5 of 5

\begin{tabular}{|l|l|l|l|}
\hline $\mathrm{PO}_{4}{ }^{3-}(\mathrm{mg} / \mathrm{L})$ & 0.46 & 0.5 & 0.5 \\
\hline $\mathrm{Cl}^{-}(\mathrm{mg} / \mathrm{L})$ & 6550.83 & 250 & 250 \\
\hline
\end{tabular}

14. WHO (2003) Chloride in Drinking-water Background document for development. WHO Guidelines for Drinking-water Quality. Guidelines for drinking-water quality. 2nd edn. Health criteria and other supporting information, World Health Organization, Geneva 2: 4.

Table 3: Mean values of physicochemical parameters from the different stations compared with different Standards.

\section{Conclusion}

The need to arrive at and effective and standard regulatory agencies to properly regulate industrial inputs into rivers is tasking and therefore need commitment. The Nigerian ecological existence is under serious environmental question with the level of unchecked or monitored effluents discharge sources. The present work suggests that the water at the effluents discharge points is polluted and therefore not fit for any form of human consumption. Therefore, adequate monitoring standards should be put in place to check both industrial and domestic sources where these effluents are initially discharged into the drainage system to enable an ecological viable environment.

\section{References}

1. Israel AU, Obot IB, Umoren SA, Mkpenie V, Ebong GA (2008) Effluents and Solid Waste Analysis in a Petrochemical Company- A Case Study of Eleme Petrochemical Company Ltd, Port Harcourt, Nigeria. E-Journal of Chemistry 5: 74-80.

2. Wokoma OAF, Edori OS (2017) Heavy metals content of an oily wastewater effluent from an oil firm at the point of discharge. International Journal of Chemistry, Pharmacy and Technology 2: 154-161.

3. Beg MU, Saeed T, Al-Muzaini S, Beg KR, Al-Bahloul M (2003) Distribution of petroleum hydrocarbons in sediment from coastal area receiving industrial effluents in Kuwait. Ecotoxicology and Environmental Safety 54: 47-55.

4. Zheng L, Wu K, Li Y, Qi Z, Han D, et al. (2008) Blood lead and cadmium levels and relevant factors among children from an e-waste recycling town in China. Environmental Research 108: 15-20.

5. Yang J, $\mathrm{Lu} \mathrm{B}, \mathrm{Xu} \mathrm{C}$ (2008) WEEE flow and mitigating measures in China Waste Management 28: 1589-1597.

6. Edori OS, Kpee F (2017) Assessment Models for Heavy Metal Pollution in Soils within Selected Abattoirs in Port Harcourt, Rivers State, Nigeria. Singapore Journal of Applied Research 7: 9-15.

7. Edori OS, Marcus AC (2017) Phytochemical Screening and Physiologic Functions of Metals in Seed and Peel of Citrullus lanatus (Watermelon). International Journal of Green and Herbal Chemistry B 6: 35-46.

8. Kpee F, Edori OS (2014) Trace metals content in shore crabs (Cardisoma guauhumi) from coastal area of Port Harcourt city, Rivers State, Nigeria. Archives of Applied Sciences Research 6: 16-21.

9. APHA (1995) Standard Methods for the Examination of Water and Wastewater. APHA, AWWA, WEF/1995, APHA Publication.

10. Edori OS, Kpee F (2016) Physicochemical and heavy metal assessment of water samples from boreholes near some abattoirs in Port Harcourt, Rivers State, Nigeria. American Chemical Science Journal 14: 1-8.

11. Chindo IY, Karu E, Ziyok I, Amanki ED (2013) Physicochemical analysis of ground water of selected areas of Dass and Ganjuwa local government areas, Bauchi State, Nigeria. World Journal of Analytical Chemistry 1: 73-79

12. Palamuleni L, Akoth M (2015) Physico-Chemical and Microbial Analysis of Selected Borehole Water in Mahikeng, South Africa. International Journal of Environmental Research in Public Health 12: 8619-8630.

13. Patil PN, Sawant DV, Deshmukh RN (2012) Physico-chemical parameters for testing of water; A review. International Journal of Environmental Sciences 3: 6-13. 